\title{
Journal of Tropical Pharmacy and Chemistry
}

Journal homepage: https://jtpc.farmasi.unmul.ac.id

\section{Antioxidants Activity of Self-Nanoemulsifying Drug Delivery System on Dayak Onions Extract (Eleutherine palmifolia) using DPPH (1,1-Diphenyl-2-picrylhydrazyl) Method}

\author{
Rahmi Annisa*, Tanaya Jati Dharma Dewi, Roihatul Mutiah, Sitti Nurjanah \\ Department of Pharmacy, Faculty of Medical and Health Science \\ Universitas Islam Negeri Maulana Malik Ibrahim, Malang, Jawa Timur, Indonesia, 65144 \\ *Corresponding author: rahmiannisa@farmasi.uin-malang.ac.id
}

\begin{abstract}
Dayak onions (Eleutherine palmifoliaL. Merr) is one plant that has been proven to have benefits as an antioxidant. The Dayak extract is formulated in the self nanoemulsifying drug delivery system (SNEDDS) because the extract has low water solubility. This study aims to develop the SNEDDS formulation system by testing its antioxidant activity. We determined whether there was an increase in antioxidant activity when formulated in the form of SNEDDS or not. The results were then compared with a solution of Dayak onions extract without using SNEDDS. The obtained formula was the optimal result that has been done before using the D-optimal mixture design method. The results of the components consisted of $50 \mathrm{mg}$ of Dayak extract, $10 \%$ caprylic triglyceride as oil, $1 \%$ tween 80 , and $6.60 \%$ transcutol as a combination surfactant, and $12.40 \%$ propylene glycol as co-surfactant. Antioxidant activity testing was carried out using the DPPH (1,1-Diphenyl-2-picrylhydrazyl) method. The antioxidant test using the DPPH method was done with two samples, namely the extract solution and Dayak onion extract SNEDDS. We elaborated the research by using a UV-VIS spectrophotometer. Each sample was made into five concentrations, namely $30 \mathrm{ppm}, 60 \mathrm{ppm}, 90 \mathrm{ppm}, 120 \mathrm{ppm}$, and $150 \mathrm{ppm}$, and carried out three times replications. The results showed that the $\mathrm{IC}_{50}$ value in the Dayak onion extract solution was $227.19 \mathrm{ppm}$ (very low), while for the SNEDDS solution for the Dayak onion extract the $\mathrm{IC}_{50}$ value obtained was $38.97 \mathrm{ppm}$ (very strong). The analysis was carried out next using an independent T-Test to obtain the results. There was no significant difference between the extract solution and the SNEDDS solution of Dayak onion extract.
\end{abstract}

Keywords: antioxidant, Dayak onion, Eleutherine palmifolia, DPPH, IC50, SNEDDS 
Antioxidants Activity of Self-Nanoemulsifying Drug Delivery System on Dayak Onions Extract (Eleutherine palmifolia) using DPPH (1,1-Diphenyl-2-picrylhydrazyl) Method

\section{Introduction}

Indonesia has various diversities so that many Indonesians prefer to use medicines derived from plants (herbal medicines). One of them is the Dayak onion plant originating from Borneo, where it has been shown to contain antioxidants. These antioxidant compounds have a very important role in human life, especially in the health sector. This is because antioxidant compounds can capture free radicals, where the free radical itself is a molecule that has one or more unpaired electrons in its wide orbital [1]. There are many compounds possessed by Dayak onions. It also has antioxidant activity, which isoliquiritigenin $\left(\mathrm{C}_{15} \mathrm{H}_{11} \mathrm{O}_{4}\right)$ included to flavonoid (chalcone) and oxyresveratrol $\left(\mathrm{C}_{14} \mathrm{H}_{12} \mathrm{O}_{4}\right)$ included to polyphenol (stilbene) [2]. Other research related to the content of compounds in Dayak onion extract also states that there is a content of naphthoquinone in Dayak onion plants [3]. Some of the compounds possessed by Dayak onion plants are groups that have very low water solubility, so a formulation is needed that can increase the solubility and bioavailability of these plants [4]. One of the formulation systems is self nano emulsifying drug delivery system (SNEDDS), which can increase bioavailability by increasing its solubility (solubility). Not only that, but several studies have also stated that the stability of the preparations made in the SNEDDS formulation is better accompanied by an increase in the antioxidant activity of the Dayak onion plant [5].

Research using the SNEDDS formulation system has been carried out using a variety of approaches. One of them is the SNEDDS formulation system for a Dayak extract that uses the HLB (Hydrophilic Lipophilic Balance) approach. The results of these studies indicated that the SNEDDS formulation was optimal, only that there was instability in the short-term storage test evaluation [6]. This research uses the SNEDDS formulation system but uses a different approach, namely using the D-optimal mixture design method, besides that the cosurfactant and oil components used are also different from previous studies. The optimal formulation obtained is then tested for antioxidant activity, and then compared with the extract solution without using SNEDDS, so that it can be seen whether there is a difference in antioxidant activity obtained from the two samples. The method used for testing antioxidant activity is the DPPH method. The DPPH method was chosen because it only requires a few reagents, and also the testing only requires a relatively short time and low cost [7]. The results obtained were then tested using a UV-Vis instrument at a maximum wavelength range of $510-520$ [8]. The absorbance obtained is used to calculate the percentage of inhibition so that the regression equation can be found and the $\mathrm{IC}_{50}$ value in each sample can be found and then a comparison is made.

\section{Materials and Methods}

\subsection{Material}

The materials in this study were Dayak onions, ethanol 96\% (Merck, Germany), methanol p.a. (Smart-Lab), distilled water, caprylic triglyceride (Sigma aldrich, USA), tween 80 (Merck, Germany), transcutol (Gattefose, France), prophylenglicol (Bratachem, Indonesia), and DPPH (1,1-Diphenyl-2-Pikrihidrazil) (Merck).

\subsection{Extraction of Eleutherine palmifolia}

Dayak onions were extracted by extraction method using $20 \mathrm{ml} 96 \%$ ethanol using the UAE method $2 \times 3$ minutes using a sonicator (Sonica, Germany) and filtered using filter paper. After that, the solvent was removed or evaporated by a rotary evaporator (BOECO, Germany). Then in the oven (UNB 500) at a temperature of $37^{\circ} \mathrm{C}$ so that the concentrated extract of Dayak onions was obtained.

\subsection{Formulation of SNEDDS Eleutherine palmifolia}

SNEDDS Dayak onion extract is made using $50 \mathrm{mg}$ of Dayak onion extract, $10 \%$ caprylic triglyceride as oil, 1\% tween 80 and $6.60 \%$ transcutol as a combination surfactant, and $12.40 \%$ propylene glycol as a co-surfactant 
made in $10 \mathrm{ml}$ of preparation. SNEDDS was made by mixing 2 surfactants (Tween 80 and Transcutol). Then mixed with a mixture of caprylic triglyceride and propylene glycol which has been weighed using analytical scales, homogenized using a magnetic stirrer (Heidolph, Germany). It was mixed with Dayak onion extract and homogenized again using a magnetic stirrer (Heidolph, Germany) so that the SNEDDS of Dayak onion extract can be obtained.

\subsection{Antioxidants activity of SNEDDS Eleutherine palmifolia}

The Dayak onion extract using SNEDDS made in the previous step was dissolved to $500 \mathrm{ppm}$ in $50 \mathrm{ml}$. A total of $5 \mathrm{ml}$ of Dayak onion extract SNEDDS solution was taken and then dissolved in $50 \mathrm{ml}$ of methanol in a $50 \mathrm{ml}$ volumetric flask until the limit mark and shaken until homogeneous (500 ppm). SNEDDS solution of Dayak onion extract with a concentration of $500 \mathrm{ppm}$ was then diluted to $10 \mathrm{ml}, 0,30,60,90,120$, and $150 \mathrm{ppm}$, by taking 0 successively. The 0,$6 ; 1,2 ; 1,8 ; 2,4$; and $3 \mathrm{ml}$ of SNEDDS solution of 500 ppm Dayak onion extract were added with $10 \mathrm{ml}$ of methanol up to the mark using a $50 \mathrm{ml}$ volumetric flask and mixed until homogeneous. After that, $4 \mathrm{ml}$ of each solution of Dayak onion extract with $0,30,60,90,120$, and $150 \mathrm{ppm}$ were prepared with the pipette and moved into the test tube. Then we added $1 \mathrm{ml}$ of DPPH solution. The blank solution used was methanol. Then it was stored in a dark room for 30 minutes and a temperature of $37^{\circ} \mathrm{C}$. After that, the absorbance of the solution at the maximum wavelength was measured using a UV Vis spectrophotometer. The absorbance obtained then calculated the percentage (\%) of inhibition against DPPH free radicals [7] using equation 1.

\subsection{Antioxidants activity of Eleutherine palmifolia extract}

The Dayak onion extract was measured at 0,05 gram, diluted in $10 \mathrm{ml}$ of methanol, and homogenized. The solution was then taken $5 \mathrm{ml}$ and diluted to $50 \mathrm{ml}$ of methanol. It was mixed until being homogenous (500 ppm). The solution of Dayak onion extract with the concentration of $500 \mathrm{ppm}$ was then diluted to
$0,30,60,90,120$, and $150 \mathrm{ppm}$ in $50 \mathrm{ml}$. We took successively $0 ; 0,6 ; 1,2 ; 1,8 ; 2,4$; and $3 \mathrm{ml}$ of Dayak onion extract of $500 \mathrm{ppm}$ and added $10 \mathrm{ml}$ of methanol until the boundary mark using $10 \mathrm{ml}$ of volumetric flask. The solution was then mixed until being homogenous.

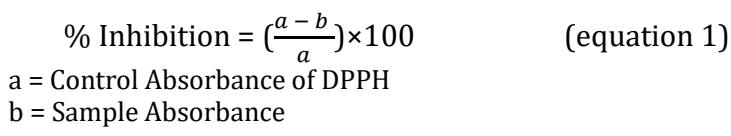

\section{Results and Discussion}

\subsection{Maximum Wavelength Measurement of DPPH}

The DPPH maximum wavelength measurement of a compound was carried out to determine the resulting absorption area, namely the absorbance value. The absorbance value obtained can provide the highest sensitivity in a measurement carried out $[9,10]$. DPPH wavelength measurements on a spectrophotometer were carried out in a wavelength range of $400-600 \mathrm{~nm}$, this is done to get the maximum absorbance. The UV-Vis spectrum obtained from the process of DPPH maximum wavelength measurement of $50 \mathrm{ppm}$ can be seen in Figure 1.

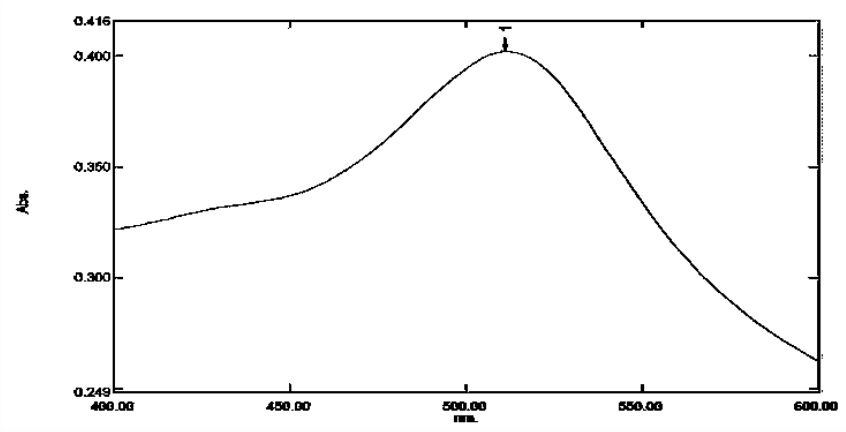

Figure 1. The measurement of maximumwavelenghtin DPPH

Based on the spectrum results obtained in Figure 1, it can be seen that the maximum wavelength of $50 \mathrm{ppm}$ DPPH which will later be 
used in measuring the antioxidant activity of the Dayak extract is $511.20 \mathrm{~nm}$ and the absorbance is 0.402 . The DPPH wavelength which has a maximum absorbance is located at $510-520 \mathrm{~nm}$. The difference in wavelength obtained can occur due to differences in the use of solvents and the detection of measuring instruments. This certainly shows that the wavelength obtained is still in the DPPH wavelength range, so it can be used in the antioxidant test of Dayak extract [8].

\subsection{Antioxidant Activity}

The antioxidant activity was carried out after obtaining the maximum wavelength of DPPH. The reason for using the DPPH method is because it is stable when used and easy to use, that is, it only needs to be dissolved, while in storage it can be for a long period if it is stored dry [11]. The working principle of DPPH is calorimetry, where antioxidants react with DPPH, the purple color of the DPPH will turn yellow so that its wavelength can be measured with a UV Vis spectrophotometer. DPPH is purple due to the relocation of electrons that occur in the hydrogen atom and will stop when it reacts with antioxidants, so DPPH will be reduced to yellow DPPH-H [12].
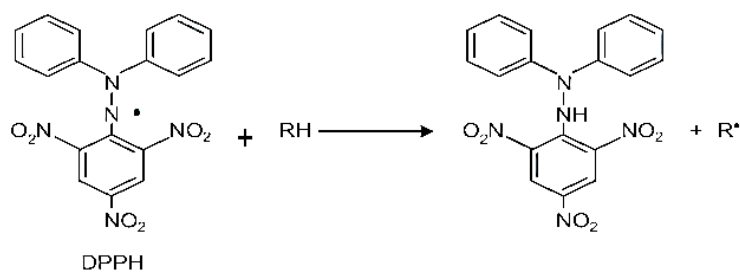

Figure 2. Inhibition mechanism of DPPH radicals [12]

Measurement and determination of antioxidant activity were carried out on 2 samples, namely SNEEDS solution of Dayak extract and Dayak extract solution as a comparison. The two samples were made into 6 concentrations, namely 30,60, 90, 120, 150 ppm with the main solution that is $500 \mathrm{ppm}$ and the solvent used in this study was methanol both in the manufacture of DPPH and the sample. It is due to the nature of methanol which can stabilize DPPH Besides, it does not affect the reaction between the sample and the DPPH solution [7].

Research states that there are several active compounds possessed by Dayak onions, including the class of alkaloid compounds, flavonoids, polyphenols, terpenes, naphthalene, and naphthoquinone and their derivatives. The percentage of each compound content in this study was seen based on the percentage of the area obtained. The compound content found most often in the study was isoliquiritigenin $\left(\mathrm{C}_{15} \mathrm{H}_{11} \mathrm{O}_{4}\right)$ included to flavonoid (chalcone) and oxyresveratrol $\left(\mathrm{C}_{14} \mathrm{H}_{12} \mathrm{O}_{4}\right)$ that is included in polyphenol (stilbene). In addition, the research also found the compound content, namely the group of naphthoquinone $\left(\mathrm{C}_{35} \mathrm{H}_{36} \mathrm{O}_{14}\right)$ with a high percentage of area. Not only that, the analysis of the content of naphthoquinone and its derivatives has also been proven using UHPLC $[2,3]$. The SNEDDS formula used was the optimal formulation in the form of $50 \mathrm{mg} / 10$ ml Dayak onion extract, $10 \%$ caprylic triglycerides as oil, $1 \%$ tween 80 and $6.61 \%$ transcutol as a combination surfactant, and $12.389 \%$ propylene glycol as a co-surfactant, while the formula Dayak extract solution as a comparison used was $50 \mathrm{mg} / 10 \mathrm{ml}$ methanol p.a. The SNEDDS formula used is expected to increase the effectiveness of the Dayak onion plant's antioxidants.

The compound of isoliquiritigenin $\left(\mathrm{C}_{15} \mathrm{H}_{11} \mathrm{O}_{4}\right)$ that is included in flavonoid (khalkon) usually has double chemical bond $\mathrm{C} 2=\mathrm{C} 3$ in conjugation with $\mathrm{C} 4$ certain group carbonyl groups, the hydroxylation pattern especially on the catechol part of the B ring, the methoxyl group, and fewer saccharide bonds which can provide higher antioxidant properties. The mechanism itself involves planarity that contributes to the shift of electrons across the next molecule and can influence the dissociation constant of the phenolic hydroxyl groups so that the entire molecule can bind to the target molecule. In addition, this compound also has a chalcone structure, where it has a hydroxyl group capable of providing hydrogen ion radicals so that it can increase its antioxidant activity during the process [13]. In general, flavonoids have the capability as an antioxidant because capable of transferring an electron to free radical compounds, where $\mathrm{R} \bullet$ is free radical 
compounds, Fl-OH is a flavonoid compound while $\mathrm{Fl}-\mathrm{OH} \bullet$ is a flavonoid radical [14]. The flavonoid reaction as an antioxidant using free radicals [14] can be seen in Figure 3.<smiles>Cc1ccc(O)c(O)c1</smiles>

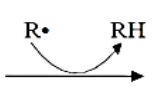<smiles>Cc1ccc(O)c([O-])c1</smiles>

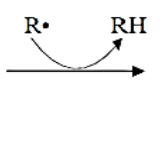

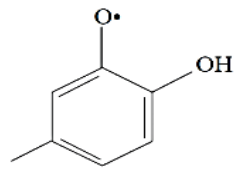

Fl-OH •

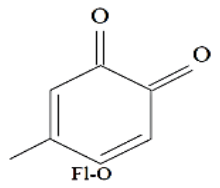

Figure 3. Radical Damping Mechanism by flavonoids [14]

Other compounds that have activity as antioxidants areoxyresveratrol $\left(\mathrm{C}_{14} \mathrm{H}_{12} \mathrm{O}_{4}\right)$ that is included in polyphenol (stilbene) and proven to catch free radicals. The group that has this function is a hydroxyl group. This polyphenol group is capable of scavenging free radicals, where polyphenols can break down free radical chain reactions, as well as suppress the formation of free radicals with the activity of enzymes or chelating metal ions which are involved in the production of free radicals. Another important antioxidant mechanism of polyphenols arises from their ability to chelate transition metals, such as iron and copper, via several hydroxyl and carbonyl groups (if any) [16]. Figure 4 the reaction of polyphenols as antioxidants with DPPH [15].

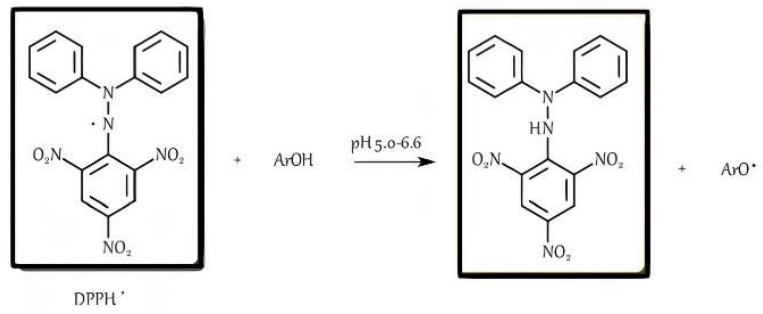

Figure4. DPPH reaction with polyphenol compounds as antioxidants
The compounds of isoliquiritigenin and oxyresveratrol have shown good radical scavenging activity which can prevent and inhibit the occurrence of oxidative stress. Antioxidants also have an important role in inhibiting the increased production of cytokines such as interleukin-6 (Il-6) or Tumor Necrosis Factor (TNF- $\alpha$ ), which are pro-inflammatory or inflammatory cytokines. Other studies have also stated that in addition to these two compounds, there is also a content of naphthoquinone which has been proven using UHPLC, where it has strong antioxidant activity due to the presence of hydroxyl groups in its structure [17, 3].

We tested the $\mathrm{IC}_{50}$ comparison of the extract solution and the SNEDDS of Dayak extract. There is a reaction between the antioxidants and DPPH, so the purple color of the DPPH will turn yellow. Its wavelength can be measured with UV-Vis. DPPH is purple due to the delocalization of electrons that occur in the hydrogen atom and will stop when it reacts with antioxidants, so DPPH will be reduced to yellow DPPH-H [12]. Measurement of the two samples using the UV-Vis instrument, two samples were tested with several variations of concentration, namely $30 \mathrm{ppm}, 60 \mathrm{ppm}, 90 \mathrm{ppm}, 120 \mathrm{ppm}, 150$ ppm which have been reacted with DPPH with three times replications. The\%inhibition at each concentration and each replication was calculated and then the mean\%inhibition rate for each concentration was calculated. Calculation of\%inhibition can be seen in the appendix. The $\%$ inhibition data for each concentration is plotted into the linear regression equation $\mathrm{y}=\mathrm{a}+\mathrm{bx}$, so that the $\mathrm{IC}_{50}$ calculation can be calculated. The following is the table of\%inhibition results and the standard curve obtained for each replication of the Dayak onion extract.

Table 1. The results of $\%$ inhibition on each solution replication of Dayak onion extract

\begin{tabular}{llll}
\hline \multirow{2}{*}{ Concentration } & \multicolumn{3}{c}{ Replication } \\
\cline { 2 - 4 } & 1 & 2 & 3 \\
\hline $30 \mathrm{ppm}$ & 109,95 & 100,75 & 110,95 \\
$60 \mathrm{ppm}$ & 107,96 & 98,51 & 89,55 \\
$90 \mathrm{ppm}$ & 107,71 & 94,78 & 70,90 \\
$120 \mathrm{ppm}$ & 29,35 & 97,26 & 10,20 \\
$150 \mathrm{ppm}$ & 40,80 & 83,08 & 6,720 \\
\hline
\end{tabular}


Table 2. The results of \% inhibition on each solution replication of SNEDDS Dayak onion extract

\begin{tabular}{llll}
\hline \multirow{2}{*}{ Concentration } & \multicolumn{3}{l}{ Replication } \\
\cline { 2 - 4 } & 1 & 2 & 3 \\
\hline $30 \mathrm{ppm}$ & 47.51 & 31.59 & 50.50 \\
$60 \mathrm{ppm}$ & 83.33 & 63.68 & 99.50 \\
$90 \mathrm{ppm}$ & 86.82 & 86.07 & 95.27 \\
$120 \mathrm{ppm}$ & 89.30 & 90.30 & 86.31 \\
$150 \mathrm{ppm}$ & 96.52 & 84.83 & 97.26 \\
\hline
\end{tabular}

The \%inhibition results in this study were obtained from calculations using absorbance after being tested using a UV-Vis spectrophotometer. The absorbance obtained has a volatile change at each concentration, so that the \%inhibition graph obtained also looks unstable or fluctuates with increasing concentration. Many things cause this instability, including the DPPH compound that is very sensitive to light. When it is exposed to light, the DPPH compound will become unstable. In addition, DPPH compounds are also sensitive to temperature. When there is a temperature change, it will result in instability in the DPPH. This is why the sample processing must also be in a dark place and cover the glassware with aluminum foil to prevent contact with light [18].

However, the results obtained are still acceptable because the $\mathrm{IC}_{50}$ values obtained are following those in the literature. The results on the regression equation on the solution of Dayak onion extract can be seen in Table 3 while SNEEDDS Dayak onion extract can be seen in Table 4.

Table 3. Results on the regression equation on the Dayak onion extract

\begin{tabular}{llll}
\hline Replication & Linear Equation & $\begin{array}{l}\mathrm{IC}_{50} \text { Extract } \\
(\mathrm{ppm})\end{array}$ & R Value \\
\hline 1 & $\mathrm{y}=0.723 \mathrm{x}+144.23$ & 130.33 & 0.7189 \\
2 & $\mathrm{y}=0.122 \mathrm{x}+105.85$ & 457.79 & 0.6953 \\
3 & $\mathrm{y}=1.0274 \mathrm{x}+146.05$ & 93.45 & 0.852 \\
\hline $\mathrm{IC}_{50}$ & & 50.33 & \\
\hline
\end{tabular}

Table 4. Results on the regression equation on the snedds of Dayak onion extract

\begin{tabular}{llll}
\hline Replication & Linear Equation & $\begin{array}{l}\mathrm{IC}_{50} \text { SNEDDS } \\
(\mathrm{ppm})\end{array}$ & R Value \\
\hline 1 & $\mathrm{y}=0.3466 \mathrm{x}+49.499$ & 1.45 & 0.7356 \\
2 & $\mathrm{y}=4.437 \mathrm{x}+31.364$ & 42.00 & 0.739 \\
3 & $\mathrm{y}=0.9411 \mathrm{x}-19.131$ & 73.46 & 0.4705 \\
\hline $\mathrm{IC}_{50}$ & & 38.97 & \\
\hline
\end{tabular}

Based on the results of the regression equation from the two sample solutions, it can be seen the graphical equation, the R-value, and the $\mathrm{IC}_{50}$ value. The purpose of obtaining a simple linear regression equation is to see the relationship between variables. The value of the correlation coefficient ( $r$ ) obtained can be interpreted according to the interpretation of the correlation coefficient version of de Vaus 2 . Exploratory, which explains the strength of the relationship between variables. Interpretation of the correlation coefficients in Table 5 [19].

Table 5. Interpretation of correlation coefficient of $d e$ vaus 2explatory

\begin{tabular}{ll}
\hline Coefficient & Correlation Strength \\
\hline 0.00 & No correlation \\
$0.01-0.09$ & Very low correlation \\
$0,10-0.29$ & Low correlation \\
$0.30-0.49$ & Moderate correlation \\
$0.50-0.69$ & Strong correlation \\
$0,70-0.89$ & Very strong correlation \\
0.90 & Almost perfect correlation \\
\hline
\end{tabular}

The value obtained shows that in the extract solution there are 2 replications with a very strong relationship between variables and 1 replication which has a strong relationship. The R-value in the SNEDDS solution of Dayak extract has 2 replications which have a very strong relationship between variables and there is 1 replication that has a moderate relationship between variables. The version coefficient ( $\mathrm{r}$ value) shows the relationship between the concentration and the \% inhibition value. Based on these results, it can be seen that a very strong relationship indicates the increasing concentration, so it has a very strong positive effect on\% inhibition, for a strong relationship it shows that an increase in concentration has a positive effect on $\%$ inhibition, while for a moderate relationship it shows that an increase in concentration has a positive effect on $\%$ inhibition. the relationship was not so strong (moderate) in affecting the $\%$ inhibition value. The coefficient value is between $-1<0<1$, which indicates that if the values are -1 then the results obtained are negatively correlated between variables if the reliability coefficient value is 1 then the relationship between the variables is perfect. The difference in the value obtained is 
not related to the activity obtained. The results obtained showed that the relationship between variables (concentration and\% inhibition) in 2 sample solutions had a different relationship strength for each replication. The reason is, as has been previously mentioned, that the\% inhibition graph obtained looks unstable or fluctuates with increasing concentration. Of course, it affects the coefficient value obtained, but these results are still acceptable because the coordinated value is (r). Stop 1 , which means that it still has a strong relationship between variables [20].

Linearity test can also be done by using the simultaneous test or the F test, which is done by comparing the calculated $\mathrm{F}$ value with the $\mathrm{F}$ table. This of course is also done to determine the quality of the relationship between variables. The rule for linearity decisions can be compared to the significant value of the deviation from linearity resulting from the linearity test (using SPSS) with the alpha value used. If the significance value of deviation from linearity> alpha (0.05) then the value is linear [21].

The results of the $F$ test of the Dayak extract solution that has been carried out can be seen that the deviation from linearity Sig. is $0.592>0.05$. These results suggest that the variables have a significant linear relationship. The calculated $\mathrm{F}$ value obtained is 1.938 , while the $\mathrm{F}$ table value can be determined using the formula (df) deviation from linearity: within groups in the significance level for nominator table, which is 3.71. The calculated $\mathrm{F}$ value was compared with the F table value, $0.665<3.71$. These results indicate a significant linear relationship in the data so that the data can be accepted. Based on the results of the $F$ test of the Dayak extract SNEDDS solution that has been carried out, it can be seen that the deviation from linearity Sig. is $0.071>0.05$ so it can be concluded that these results have a significant linear relationship between variables. The calculated $\mathrm{F}$ value obtained is 3.191 , while the $\mathrm{F}$ table value can be determined using the formula (df) deviation from linearity: Within Groups in the Degrees of Freedom for Nominator table, which is 3.71. The calculated $F$ value is compared with the F table value, $3.191<3.71$. This of course also indicates that there is a significant linear relationship in the data so that the data can be accepted. The two linearity results obtained both show a significant relationship between variables so that it can be accepted. The $\mathrm{IC}_{50}$ results obtained showed that the $\mathrm{IC}_{50}$ value obtained in the Dayak onion extract solution was $227.19 \mathrm{ppm}$, while for the SNEDDS solution for Dayak onion extract the $\mathrm{IC}_{50}$ value obtained was $38.97 \mathrm{ppm}$. The antioxidant activity is divided into several categories as shown in Table 6 [22].

Table6. Range Value of $\mathrm{IC}_{50}$ and the Category of Antioxidant Activity

\begin{tabular}{ll}
\hline $\mathrm{IC}_{50}$ Value & Category \\
\hline$<50$ & Very strong \\
$50-100$ & Strong \\
$100-150$ & Moderate \\
$150-200$ & Low \\
$200-500$ & Very low \\
$>500$ & No antioxidant activity \\
\hline
\end{tabular}

Based on Table 6, it can be seen that the $\mathrm{IC}_{50}$ value of antioxidant compounds obtained from the Dayak onion extract solution is in the range of 200-500 ppm so that it has very low activity. While the antioxidants obtained from the SNEDDS solution of Dayak onion extract were $<50 \mathrm{ppm}$. It showed that the antioxidants from the SNEDDS solution had very strong antioxidant activity. This shows that the antioxidants from SNEDDS have very strong antioxidant activity. The antioxidant activity possessed by Dayak onions has very weak antioxidant activity. This is because several causes include DPPH compounds that are very sensitive to light so that when exposed to light, DPPH compounds will become unstable. DPPH compounds are also sensitive to temperature, so when there is a temperature change it will result in instability in the DPPH. This is why the sample processing must also be in a dark place and cover the glassware with aluminum foil to prevent contact with light [17]. If when the test is carried out, the DPPH solution is exposed to light or experiences a high or low-temperature change, the DPPH will experience instability so that the absorbance obtained is also unstable, and the antioxidant activity obtained will also decrease. The results on the SNEDDS of Dayak onion extract were that the antioxidant activity in this preparation was proven to be able to 
increase the antioxidant activity of the Dayak extract.

Independent Analysis T-Test is a test used to determine the average difference between 2 populations or independent data groups. This independent T-test has several conditions or assumptions that must be met, including [23] 1) Data is normally distributed, 2) Both groups are independent data, and 3) Variablethat is correlated is numerical and categoric (within two groups). The three requirements have been fulfilled, where the normality test is carried out by entering the $\mathrm{IC}_{50}$ result data for each replication. The results of the normality test obtained are normally distributed data. The data normality test used was Shapiro-Wilk. This is because the data tested $<30$ and based on the Sig value. or significance or probability value generated $>0,05$. The two groups that exist are also independent data groups and the variables only consist of 2 groups.

Based on the SPSS output obtained, it can be seen that the Levene's Test value which is a statistical technique to test the variance between the two groups shows a result of 0.036 less than 0.05 so that the Levene's Test value shows significant results because $0.036<0.05$, and the results indicate that the data is not homogeneous. The homogeneity test itself is a statistical test procedure that is intended to show that two or more groups of sample data tested come from populations that have the same variance. Based on the results obtained, it shows that the data is not homogeneous. The data that is not homogeneous can be due to poor data distribution, but independent t-test analysis can still be done, however, to read the results of the test is in the Equal Variance Not Assumed column (assuming different variants) [24]. The results of the independent t-test Sig. seen in the first row because the data shows significant results (not homogeneous). Sig. the resulting value is 0.243 , which means Sig. obtained is greater than 0.05 , so it can be seen that the $\mathrm{IC}_{50}$ obtained between the two samples, namely SNEDDS extract solution and Dayak onion extract solution without SNEDDS does not have a significant difference [23].

The absence of this significant difference could be due to several reasons, including the instability of the DPPH solution which is very sensitive to light and temperature so that it affects the antioxidant activity test carried out [16]. In addition, it can also be due to the formulation used is still unstable so that when the test is carried out the antioxidant activity test, which causes a decrease in the activity of antioxidant compounds possessed by Dayak onions. The $\mathrm{IC}_{50}$ results obtained from this study showed that SNEDDS was only able to slightly increase the antioxidant activity of Dayak onions, namely 38.97 (very strong category of antioxidant activity), while the resulting extract solution without SNEDDS was 227.19 (very low category antioxidant activity)and the two results did not show a significant difference, with the results obtained were $\mathrm{H}_{0}$ accepted and $\mathrm{H}_{\mathrm{a}}$ rejected, where there was no difference between the SNEDDS solution of Dayak onion plant extract and the Dayak extract solution, which was seen based on the results of the antioxidant effect of $\mathrm{IC}_{50}$.

The SNEDDS formulation system is carried out with the aim that it can increase the effectiveness of compounds and drug bioavailability in the body by increasing drug solubility (drug solubility), in which it is said that the drug is insoluble in water but will readily dissolve in oil. The permeation of the drug will penetrate the intestinal membrane better because of the small droplet size [5]. SNEDDS preparations, in general, can also experience instability, where the instability of SNEDDS that occurred in previous studies can be seen from the phase separation that occurred at storage on day 14 . Another study states that the phase separation that occurs when storage is carried out can of course also result in a decrease in the activity of the compound or the efficacy of the drug. Related research also explains that in some cases the preparation of nanoemulsions requires a higher amount of surfactant than oil, if less surfactant is used it will cause instability in the preparation. Of course, it can be seen that the combination surfactant used is not more than the oil used in this study. It is what allows instability in the SNEDDS preparations made [24, 25]. Another study also stated that instability during storage can occur due to the influence of the concentration of surfactants or cosurfactants, where the free energy in oil globules becomes large, the increased cohesion force will cause oil globules to combine to form larger globules 
[26]. Future study related to the parameter of antioxidant activity in Dayak onion extract and solution using different methods is required.

\section{Conclusions}

Based on the results of the research that has been done, it can be concluded that the value of $\mathrm{IC}_{50}$ obtained for the Dayak onion extract solution was $227.19 \mathrm{ppm}$. It was included in the category of very low antioxidant activity while the SNEDDS solution of Dayak onion extract was $38.97 \mathrm{ppm}$ and included in the very strong antioxidant activity category. The antioxidant activity obtained from the two samples (SNEDDS solution of Dayak onion extract and Dayak onion extract solution) did not have a significant difference in antioxidant activity based on the $\mathrm{IC}_{50}$ of the two sample solutions.

\section{Acknowledgments}

The authors wish to thank the Pharmacy Department of State Islamic University Maulana Malik Ibrahim of Malang for providing the facilities to conduct this study.

\section{Authors Contribution}

Concept - R.A; Experimental section - R.A., T.J.D., R.M; Data Collection and Processing - R.A., S.N.J; Analysis and Interpretation - R.A., T.J.D., R.M., S,N.J; Literature Search - S.N.J ; Writing R.A., S.N.J; Critical Reviews R.A., T.J.D., R.M., S,N.J

\section{Conflicts of Interest}

The authors declare no conflict of interest.

\section{References}

[1] Pratiwi, D., Sri Wahdaningsih, danIsnindar. 2013. The Test of Antioxidant Activity From Bawang Merah Leaves (Eleutherine americana MERR.) Using DPPH (2,2- Diphenyl 1Picrylhydrazyl) Method. Trad. Med. J. Vol. 18 No. 1

[2] Mutiah, Roihatul, Trian Sidha Minggarwati, Risma Aprinda Kristanti, Erna Susanti.2019. Compound Identification and Anticancer Activity of Ethyl Acetate Fraction from Bawang Sabrang (Eleutherine palmifolia(L.) Merr.) on HeLa Cervical Cancer Cell Line. Indones. J. Cancer Chemoprevent., Vol. 10 No. 3, 131-139
[3] Annisa, R., E Hendradidan M Yuwono. 2020. Analysis of 1,4naphthoquinone in the Indonesian medical plant from extract Eleutherine palmifolia (L.) Merr by UHPLC. IOP Conf. Series: Earth and Environmental Science 456

[4] Laguerre, M., Bayrasy, C., Panya, A., Weiss, J., Mc. Clements, D.J., Lecomte, J., Decker, E.A., Villeneuve, P. 2015. What Makes Good Antioxidants in Lipid-Based Systems? The Next Theories Beyond the Polar Paradox. Crit. Rev. Food Sci. Nutr. 55, 183-201.

[5] Gupta, S., Chavan, S., danSawant, K. K. 2011. SelfNanoemulsifying Drug Delivery System for AdefovirDipivoxil: Design, Characterization, in Vitro and ex Vivo Evaluation. Physicochem. Eng. Aspects. 392

[6] Annisa, R., E Hendradidan M Yuwono. 2020. Design and optimization of Eleutherine palmifolia extract-loaded SNEDDS using HLB approach. J Res Pharm Vol. 24 No. 6

[7] Molyneux, P. 2004. Penggunaan radikal bebas yang stabil diphenylpicryl- hydrazyl (DPPH) untuk memperkirakan aktivitas antioksidan. Jurnal Sains dan Teknologi Songklanakarin, Vol. 26 No. 2 (211-219)

[8] Miliauskas, G., P. Venkutonis, dan T.A Van Beck. 2004. Screening of Radical Scavenging Activity of Some Medicinal and Aromatic Plant Extracts. J. Food Chem. Vol. 85 No. 2, 231-237

[9] Sukmawati, Sri Sudewi, Julius Pontoh. 2018. Optimasi dan Validasi Metode Analisis dalam Penentuan Kandungan Total Flavonoid pada Ekstrak Daun Gedi Hijau (Abelmoscus manihot L.) yang DiukurMenggunakanSpektrofotometer UV-Vis. Jurnal Ilmiah Farmasi - UNSRAT Vol. 7 No. 3

[10] Hidayati, Jelita Rahma, Ali Ridho, Rini Pramesti. 2017. Aktivitas Antioksidan Ekstrak Rumput Laut Padina sp. Dari Perairan Bandengan Jepara dengan Metode Transfer Elektron Buletin Oseanografi Marina Vol. 6 No. 1

[11] Packer, L.M., Hiramatsu, T. and Yoshikawa. 1999. Antioxidant Food Supplement in Human Health. Academic Press

[12] Reynertson, K. A. 2007. Phytochemical Analysis of Bioactive Constituens from Edible Myrtaceae Fruit, Dissertation. New York: The City University of New York

[13] Franch PC., Belles, V.V., Codoner, A.A. and Iglesias, E.A., 2011. Oxidant mechanisms in childhood obesity: the link between inflammation and oxidative stress. Translational Research158: 369-84

[14] Kandaswami, C and Middleton, E. 1997. Flavonoids as antioxidant, In F. Shahidi (Ed). Natural Antioxidant Chemistry, Health Effects 
and Applications. Champaign Illions : AOCS Press.

[15] Warsi and Sholichah, A. R. 2017. Phytochemical Screening and Antioxidant Activity of Ethanolic Extract and Ethyl Acetate Fraction from Basil Leaf (Ocimum basilicum L.) by DPPH Radical Scavenging Method. International Proceeding. IPCUAD2017. IOP Publishing, IOP Conf. Series: Materials Science and Engineering; 259; 012008.

[16] Leopoldini M, Marino T, Russo N, Toscano M. 2011. Antioxidant properties of phenolic compounds: H-atom versus electron transfer mechanism. The Journal of Physical Chemistry A. 108: 4916-4922.

[17] Mutiah, Roihatul, Trian Sidha Minggarwati, Risma Aprinda Kristanti, Erna Susanti. 2019. Compound Identification and Anticancer Activity of Ethyl Acetate Fraction from Bawang Sabrang (Eleutherinepalmifolia(L.) Merr.) on HeLa Cervical Cancer Cell Line. Indones. J. Cancer Chemoprevent., Vol. 10 No. 3, 131-139

[18] Nahat, Putri Maharani M.T., Tuty Putri Sri Muljati, Nurcholis. 2017. Kandungan Asam Sianida dan Aktivitas Antioksidan Pada Kluwak (PangiumeduleReinw.) Setelah Proses Perebusan. Analisis Kesehatan Sains Vol. 6 No. 2

[19] Alaydrus, Ahmad Migdad, dan Sarwono Hardjomuljadi. 2018. Analisis Faktor Keterlambatan Dimulainya Pelaksanaan Proyek konstruksi Pada Model Kontrak Rancang Bangunan. Jurnal Konstruksia Vol. 10 No. 1
[20] Sudjana. 2005. Metode Statiska. Bandung: Tarsito

[21] Gunawan, R. 2005. Analisis Regresi Linier Ganda dengan SPSS. Yogyakarta: Ghaliallmu

[22] Jun, M., Fu, H. Y., Hong, J., Wan, X., Yang, C. S., \&Ho, C. T. 2003. Comparison of Antioxidant Activities of Isoflavones from Kudzu Root (PuerarialobataOhwi). Journal of Food Science, Vol. 68 No. 2, 2117-2122.

[23] Nuryadi, Tutut Dewi Astuti, Endang Sri Utami, M. Budiantara. 2017. Dasar-Dasar Statistik Penelitian. Yogyakarta: Sibuku

[24] Tyastirin, Esti dan Irul Hidayati. 2017. Statistik Parametrik Untuk Penelitian Kesehatan. Surabaya: Program Studi Arsitektur UIN Sunan Ampel

[25] Sulastri, Evi., Mohammad Ikram, Yuliet. 2017. Uji Stabilitas dan Antioksidan Mikroemulsi Likopen Tomat (SolanumlycopersicumL.). Galenika Journal of Pharmacy Vol. 3 No. 1

[26] Sarmah, S., Subrata B.G., Fan X., Annanya A.B. 2019. Characterization and Identification of The Most Appropriate Nonionic Surfactant For Enhanced Oil Recovery. Journal of Petroleum Exploration and Production Technology, Vol. 9 No. 34, 383.

[27] Noor, Siti Umrah dan Amelia Gozali. 2018. Pengaruh Konsentrasi Ekstrak Teripang Emas (Stichopushermanni) Terhadap Aktivitas Antioksidan Nanoemulsi Minyak Biji Anggur. Jurnal Ilmu Kefarmasian Indonesia Vol. 16 No. 1 